University of Wollongong

Research Online

Faculty of Business - Papers (Archive)

Faculty of Business and Law

2013

Trade liberalisation and manufacturing wage premiums: evidence from Thailand

Kankesu Jayanthakumaran

University of Wollongong, kankesu@uow.edu.au

Piyapong Sangkaew

University of Wollongong, ps650@uowmail.edu.au

Martin O'Brien

University of Wollongong, martinob@uow.edu.au

Follow this and additional works at: https://ro.uow.edu.au/buspapers

Part of the Business Commons

Research Online is the open access institutional repository for the University of Wollongong. For further information contact the UOW Library: research-pubs@uow.edu.au 


\title{
Trade liberalisation and manufacturing wage premiums: evidence from Thailand
}

\begin{abstract}
This paper investigates trade related industrial wage premiums. The procedure involves (1) estimating industrial wage premiums and (2) linking those estimated wage premiums to trade related variables. Results reveal that (1) in addition to workers' characteristics, industry characteristics where workers are employed were important in determining the wages for workers, (2) falling output tariffs resulted in increased wage premiums, and (3) an increase in intermediate imports exerted a strong positive influence on wage premiums. Linked employer and employee micro data may provide further insights which are currently not available.
\end{abstract}

Keywords

era2015, wage, manufacturing, thailand, liberalisation, evidence, trade, premiums

Disciplines

Business

Publication Details

Jayanthakumaran, K., Sangkaew, P. \& O'Brien, M. (2013). Trade liberalisation and manufacturing wage premiums: evidence from Thailand. Journal of Asian Economics, 29 (2013), 15-23. 


\title{
Trade liberalisation and manufacturing wage premiums: evidence from Thailand
}

\author{
by
}

Kankesu Jayanthakumaran*, Piyapong Sangkaew and Martin 0’Brien

\section{INTRODUCTION $^{1}$}

Over recent decades the Thai government has pursued an aggressive trade liberalisation policy consisting of reduced tariffs and non-tariff barriers alongside restrictions on foreign direct investment. While some previous studies have looked at how these reforms influenced wage inequality in general (Bhula-or and Kripornsak 2008; Velde and Morrissey, 2004), none have specifically looked at the link between the reforms and changing industry skill premiums. Our investigations reveal that there has been a divergence in the trends of output and employment within the manufacturing sector which may be explained by labour productivity (see Figures 2 and 3). Certain firms and industries are growing faster than others, and as a consequence, are demanding proportionately more skilled workers. With this background in mind, this paper intends to fill the existing research gap on the estimation of industrial wage premiums and focus on the link between these wage premiums and trade liberalisation.

This study is the first study of its kind to examine Thailand using Krueger and Summers' (1988) two step procedure. This procedure involves (1) estimating industrial wage premiums after controlling for other salient worker characteristics such as education, experience, and gender (see for details, Seguino, 2000; Hunt, 2002; Earle, 2010) and (2) linking these estimated wage premiums to trade related variables such as tariffs, exports per worker, intermediate input imports and foreign direct investment, after controlling for other variables such as labour productivity using an ISIC two digit sub-sector panel (for details see Goldberg

1 The results and data in this paper come from Sangkaew's unpublished dissertation (Sangkaew, 2013). The authors would like to thank the anonymous referees of this journal for useful comments. The usual disclaimers apply.

*Corresponding author Tel.: +02 4221 4029; Fax: +02 4221 3725; E - mail address: Kankesu@uow.edu.au. (K. Jayanthakumaran). 
and Pavcnik, 2007; Mishra and Kumar, 2005; Ferreira et al., 2007). At present Thailand's National Statistical Office do not link employer and employee data so this study uses individual level data from Labour surveys for the $1^{\text {st }}$ stage of the analysis to estimate wage premiums at the ISIC two-digit sub-sector level, and ISIC two-digit panel data from Industrial surveys for the 2nd stage.

The next section briefly outlines the theoretical links between trade liberalisation and wage inequality, complemented by published empirical evidence. Section 3 highlights observable patterns in trade liberalisation and real wage data in Thailand. Section 4 details the methodology used in our empirical work, followed by our empirical results in section 5 . Policy implications and concluding remarks are presented in the final section.

\section{TRADE LIBERALISATION AND WAGE INEQUALITY}

An increase in real wages is a common indicator of improved industrial performance and economic development. Fundamental economic theory states that wages in an industry are dependent upon the prices of goods and services produced and the marginal product of labour (under the assumption of perfect competition and worker are immobility). Any decline in import tariffs as part of trade liberalisation would presumably lower the profit margins of domestic firms and cause a proportional declines in wages. In the long run, when factors of production are mobile across industries, standard Heckscher-Ohlin's theory would predict that factor prices will be equalised across industries and any differences in wages for similar types of work will eventually disappear.

However, imperfectly competitive product and labour markets should react in a different way. Trade liberalisation would lower the profit margins of domestic firms relative to the previously protected environment, which therefore lowers industrial wages. The decline in import tariffs could be associated with subsequent improvements in productivity, with the expectation that this would reflect in higher wages across industries reliant upon these inputs. This will eventually lead to some industries operating with sustained higher wage premiums than others. 
According to Heckscher-Ohlin's predictions, increased trade openness should narrow the wage gap between skilled and unskilled in developing countries due to an increase in the demand for the abundant of unskilled labour. However, empirical studies examining the link between trade liberalisation and industry sector wage premiums in developing countries have shown varied results since analysis began with Krueger and Summers (1988). Studies that have found that trade reforms narrowed the wage gap between skilled and unskilled workers across manufacturing industries include Amiti and Cameron (2012) and Kumar and Mishra (2008). However, Goldberg and Pavcnik (2007) ${ }^{2}$ contend that trade liberalisation has resulted in an increased the wage gap in most developing countries, contradicting Heckscher-Ohlin's predictions. $^{3}$

Some recent studies have deviated from traditional neoclassical thought in favour of a structural heterogenous-firm model in order to explain the impact of trade on wage dispersion within occupations and sectors. ${ }^{4}$ For example, Helpman et. al. (2012) used a heterogenousfirm model applied to Brazil and concluded that further trade liberalisation can have a sizeable impact on increasing the wage gap if trade costs decline sufficiently. Furthermore, if the percentage of exporting firms increases to a critical point, the wage gap reaches a peak but then begins to fall back. The challenge here is that matched employer-employee data covering the heterogeneity of firms, plants, products, and workers is desirable to conduct such analyses, however, this type of data is not widely available, and not currently collected by the Thai National Statistical Office.

There are three ways labour markets can adjust to trade liberalisation in an intra-industry framework (Davis and Harrigan, 2011). First, such an adjustment can be smooth, without any firms closing down and no resulting job losses, with an overall rise in welfare as the price index falls as the result of increased variety gains (Krugman, 1981). Second, gains can come

\footnotetext{
${ }^{2}$ Goldberg and Pavcnik (2007) surveyed the impact of globalisation on income inequality in developing countries. This survey also incorporated wage premium related studies.

${ }^{3}$ Helpman et.al. (2012: 1) argued that "these apparently discordant empirical findings are in fact consistent with a trade-based explanation for wage inequality, but one rooted in recent models of firm heterogeneity rather than neoclassical trade theories.”

${ }^{4}$ Helpman et.al. (2012: 1) citing Katz and Murphy (1992) argued that "much of the changes in the relative demand for skilled and unskilled workers in developed countries has occurred within sectors and occupations rather than across sectors and occupations.............neoclassical trade theory is not able to elucidate it.”
} 
through expanding the output of high productivity firms and closing down low productivity firms, where Krugman’s variety gains disappear entirely (Melitz, 2003). Third, international trade can costs jobs and lowers wages, but there will be a minimal impact on aggregate unemployment and substantial aggregate gains (Davis and Harrigan, 2011).

In summary, the theoretical framework of international trade policy is validated by the empirical studies on trade-related wage performance. Recent studies have deviated from neoclassical ideology and focused more on theory-based structural heterogenous-firm analysis. In the neoclassical-based studies, inconsistency in time, country and methodology is an obstacle to meaningful comparisons and outcomes.

\section{TRADE LIBERALISATION AND THE LABOUR MARKET IN THAILAND}

In response to an unprecedented trade deficit in 1969 the Thai government increased both tariff and non-tariff barriers. This move resulted in an increase in the Nominal Rate of Protection (NRP) for both consumer non-durables and durables to around 44 per cent (Phan, 2004). However, subsequent government moves in the 1980s to reduce protection in the manufacturing sector did not produce the desired results. With a stronger fiscal position in the early 1990's a substantial reduction of tariffs and non-tariff barriers was again initiated in the manufacturing sector. The Effective Rate of Protection (ERP) for the manufacturing sector as a whole was been reduced from 53 per cent in 1990 (Booncharoen, 2001) to 24.4 per cent in 2003 (Jongwanich \& Kohpaiboon, 2007). These reductions were not across the board and differed for various sub-sectors within the manufacturing. For example, the ERP for nonmetal products was reduced from 108.5 per cent in 1985 to 19.3 per cent in 2003, whereas paper and pulp decreased from 53.5 per cent to 32.2 per cent (Jongwanich and Kohpaiboon, 2007).

Some characteristics of the Thai labour market which may influence wages and wage setting practices include low trade union coverage, the presence of minimum wages law, and a relatively large immigrant labour force. In 1998 only 2.9 per cent of wage earners in the private sector were members of a labour union, compared to approximately 11 per cent in the Philippines and South Korea (National Statistical Office, 1998). In addition, since 1991 state enterprise employees have been prohibited from forming unions. Therefore, the influence of 
unions on wages is expected to be minimal. A minimum wage law in Thailand has been enforced in Bangkok and the metropolitan area since 1972, and was extended nationwide in 1974. An amendment to the Labour Protection Act in 1998 allowed for adjustments to the minimum wage subject to the cost of living, inflation, standard of living, cost of production, firms' competitiveness, labour productivity, and other economic and social conditions. Immigrant workers (mainly illegal) from Burma, Laos, and Cambodia constituted approximately 5 per cent of the labour force in 2005, performing mostly unskilled work. Bryant and Rukumnuaykit (2007) estimated that a one per cent increase in immigrant workers to the total labour force causes wages to decrease by around 0.46 per cent.

Real wages in the agricultural, non-agricultural, and manufacturing sectors are displayed in Figure 1. We can see that even though real wages in all sectors increased from 2001 to 2009, those in the non-agricultural sector (which includes manufacturing) have consistently remained the highest. The wages of non-agricultural workers are around four times higher than agricultural workers, while wages in the manufacturing sector are around 2.5 times higher than the agricultural sector. In the Thai manfacturing sector, real wages exhibited a short term decrease between 2001 and 2003, but have gradually increased thereafter.

Figure 1: Real Wage by Sector: 2001 - 2009 (in Baht)

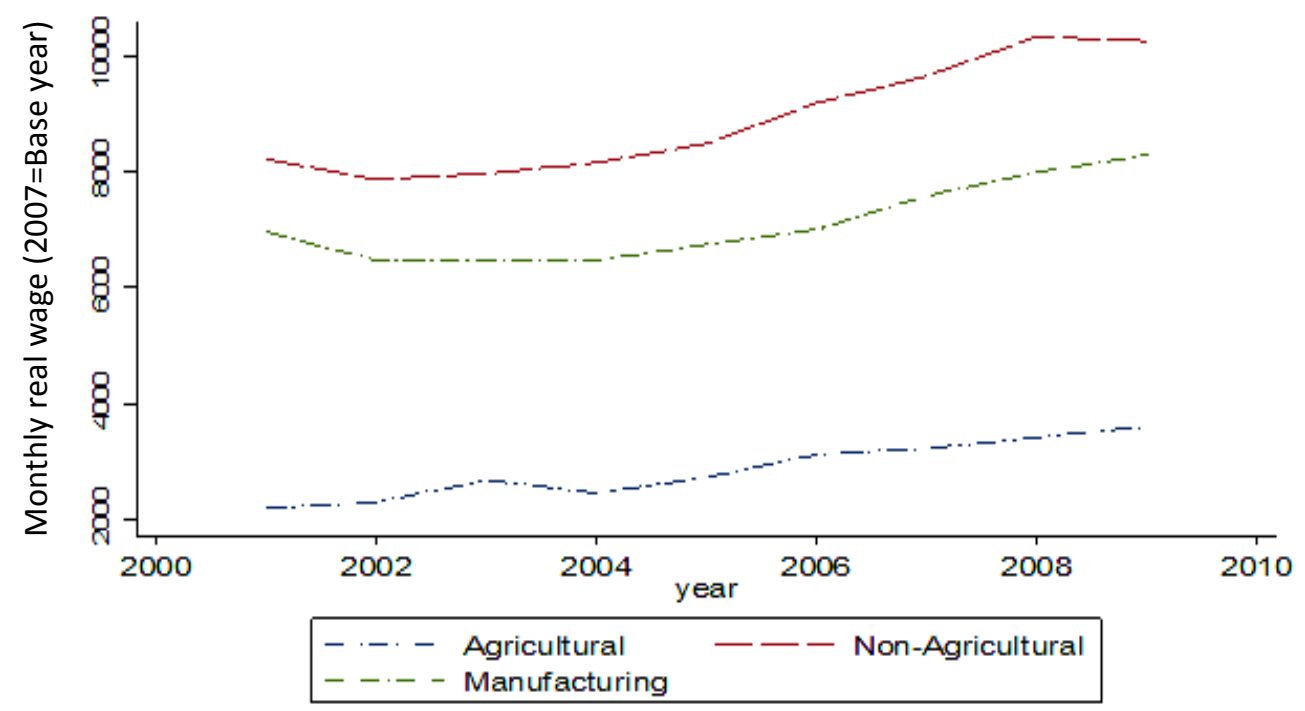

Note: 31 Baht = 1 US Dollar and Non-Agricultural sector indicates service and manufacturing sectors. Source: Bank of Thailand (2010a) 
Figure 2 shows the contribution of Thai manufacturing to both aggregate employment and output. It is apparent that the percentage of manufacturing employment to total employment has not kept up with the increase in manufacturing GDP to total GDP. Manufacturing output as a percentage of GDP displays a steadily increasing trend that is not reflected in the employment pattern. In fact the percentage of total employment in manufacturing actually decreased from 15.3 per cent in 2000 to 14 per cent in 2010. This divergence of trends may be explained by increasing labour productivity which allowed the manufacturing firms to produce higher output from fewer workers. Figure 3 shows that the labour productivity index ${ }^{5}$ of manufacturing has increased from around 105 in 2001 to 160 in 2011. Labour productivity grew by approximately 1.3 per cent per annum from 1991 to 2001, increasing to 5.0 per cent per annum from 2001 to 2011 when we observed the different trends. In comparison, the annual average agricultural growth was around 1.0 percent during the same period.

\section{Figure 2: Percentage of the Thai Manufacturing Employment and Manufacturing GDP.}

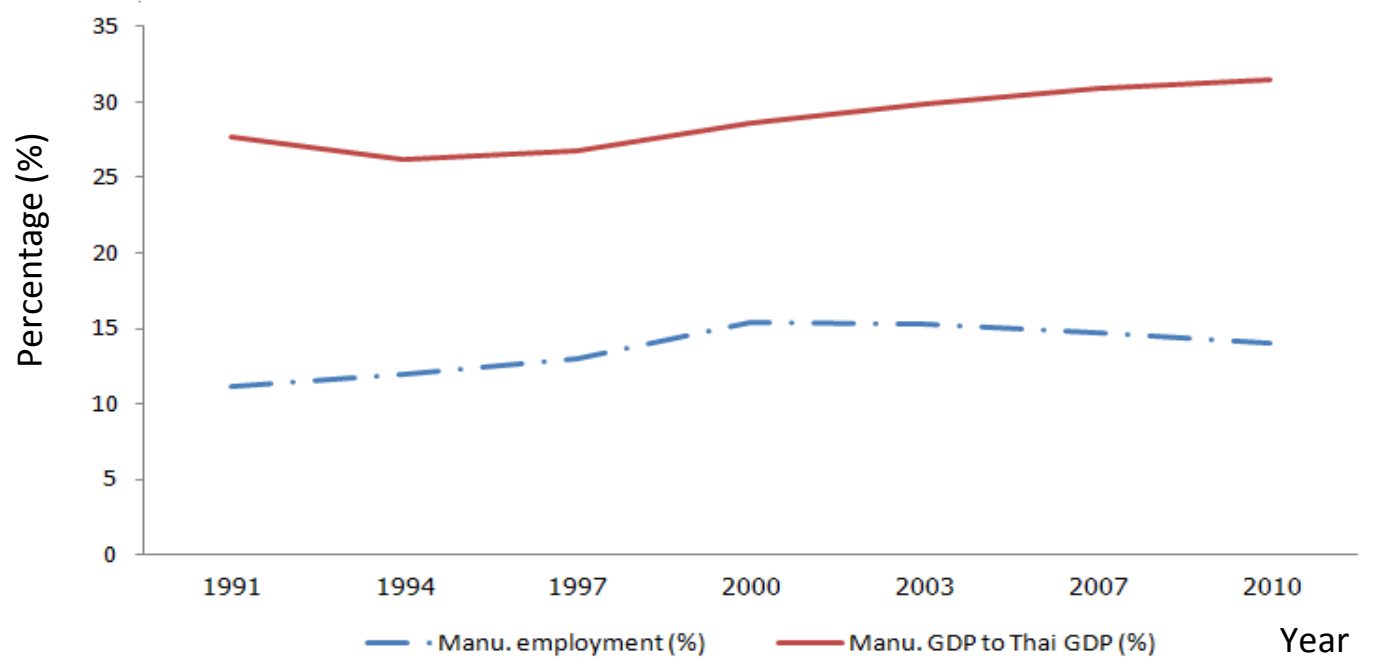

Source: National Economic and Social Development Board (2012a).

\footnotetext{
${ }^{5}$ The labour productivity indexes of the manufacturing sector and agricultural sectors are the labour productivity of both sectors relative to the average labour productivity of the whole sector, by regarding 2001 as the base year (Bank of Thailand, 2012a).
} 
Figure 3: Labour Productivity Index by Sector: 2001 - 2011

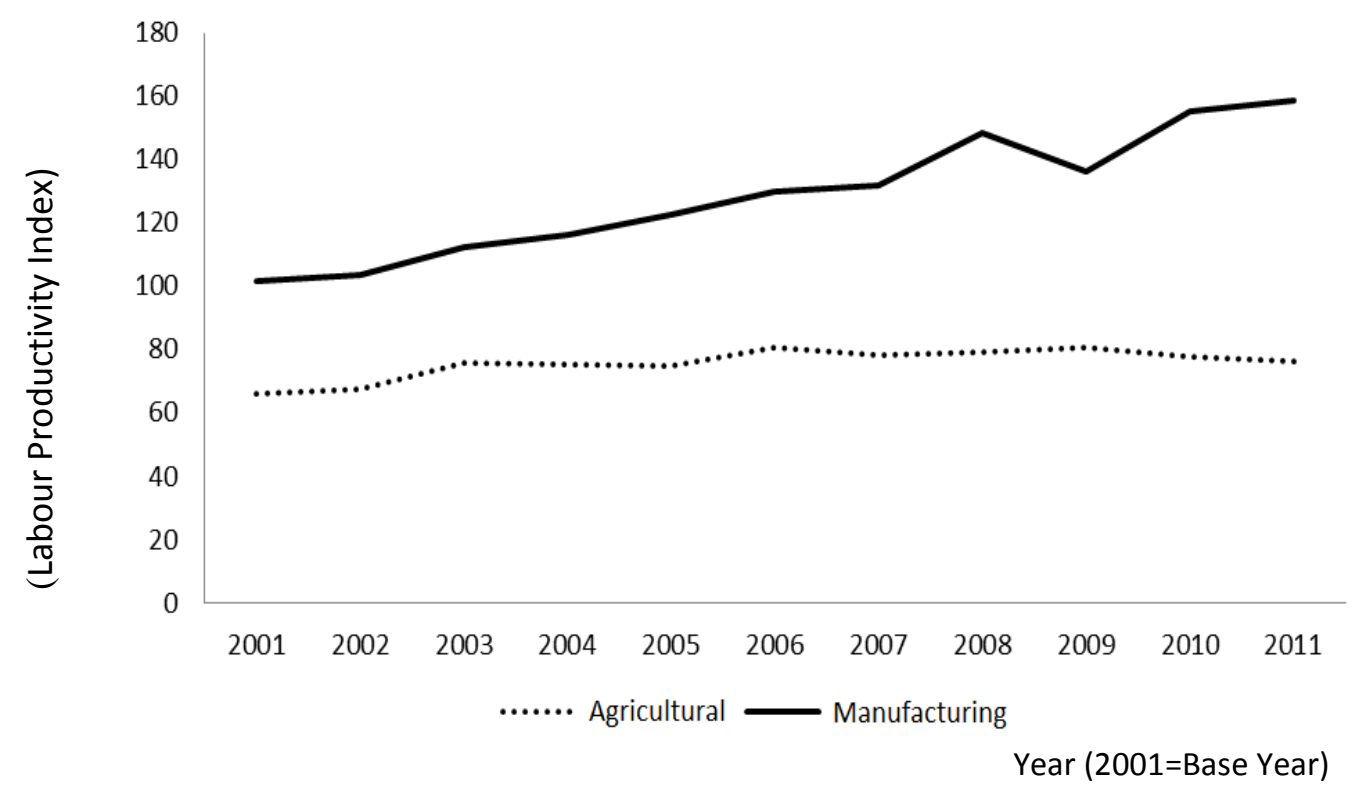

Source: Bank of Thailand (2010b)

Both Labour and Industrial surveys unambiguously reveal that certain firms and industries have been growing faster than others, and are demanding proportionately more skilled workers. The proportion of skilled to unskilled wages, defined as the wage package of nonproduction and production workers has also grown (Feenstra \& Hanson, 1996). The increase in skilled labour has been aided by a changing educational composition of the labour force. Figure 4 show that the proportion of workers who completed secondary school has increased from 22 per cent in 1994 to 30 per cent in 2010. The share of employed university graduates has fluctuated over time and dropped sharply between 1997 and 2000 during the time of the Asian Crisis, subsequently increasing from 9 per cent in 2003 to 16 per cent in 2010. Overall, the employment growth of university trained workers has increased by around 5 per cent per year. 
Figure 4: Employment by Education in Thailand: 1994 - 2010

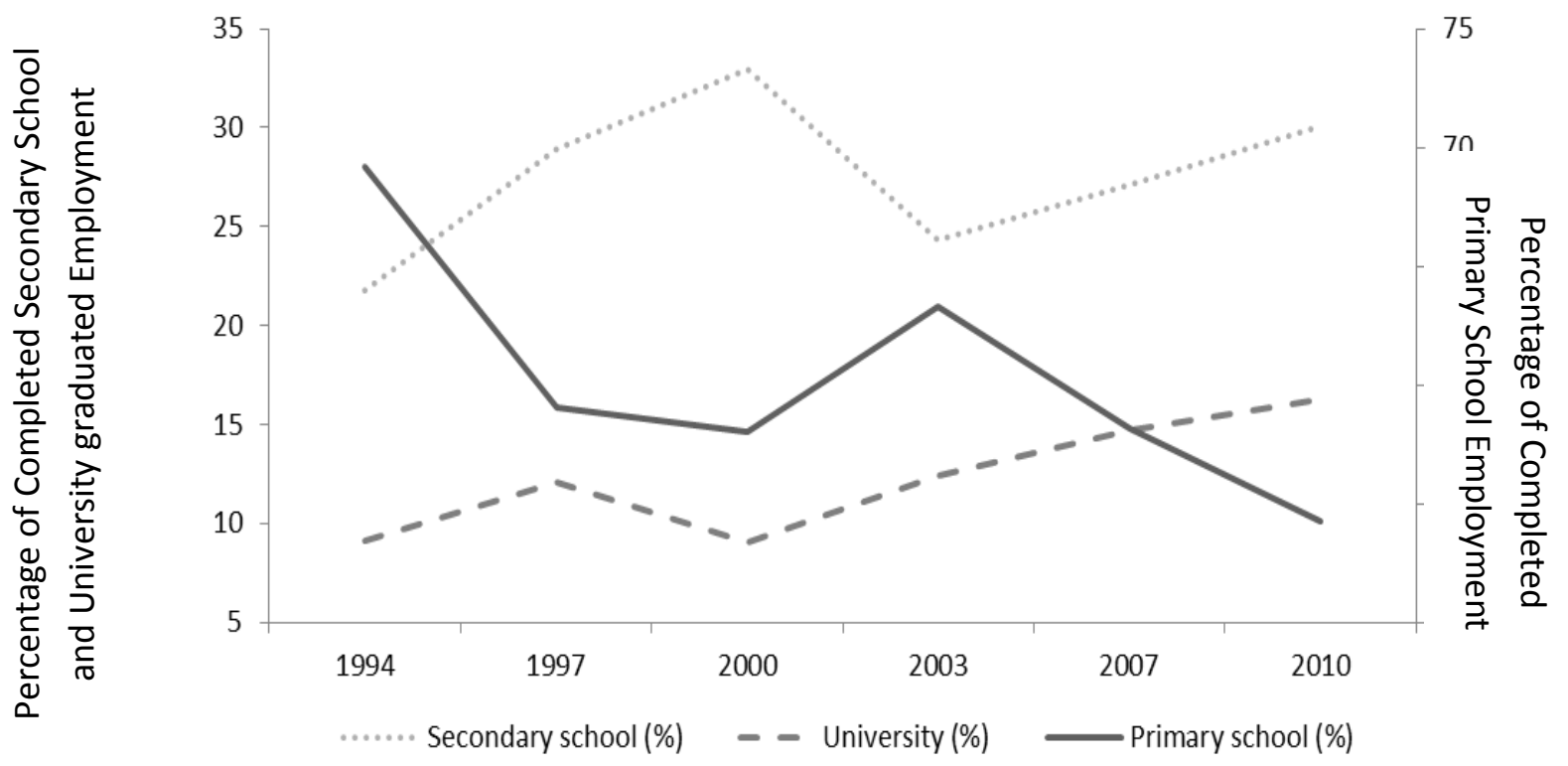

Source: The National Economic and Social Development Board (2012b) and the Bank of Thailand (2012b).

\section{METHODOLOGY}

\subsection{Estimating Manufacturing Sector Wage Premiums (first stage)}

Following the methodology of Krueger \& Summers (1988) a two stage estimation procedure has been adopted by (a) estimating industry sub-sector wage premiums after controlling for worker characteristics using employee level data, and (b) linking these wage premiums with explanatory variables reflecting labour market and trade liberalisation using industry subsector data.

National Statistical Office Labour Force Surveys of 1991, 1994, 1997, 2000, 2003 and 2007 have been used to estimate industry wage premiums. The number of observations used ranges from 9908 in 1991 to 50599 in 2007. Statistical data that collected in this survey includes: (i) age, sex, educational attainment, occupation, marital status, and labour force status of the population, (ii) occupation, industry, work status, work hours, income and other fringe 
benefits of employed persons, (iii) time spent looking for a job, previous occupation, and job search methods of the unemployed.

The empirical model used to estimate the wage premium follows a standard wage model specification, and is formulated as follows,

$\ln ($ WAGE $)=f($ AGE, GENDER, MARITAL STATUS, EDUCATION, LOCATION, INDUSTRY SUB SECTORS)

A worker's monthly wages (in 2007 constant prices) are expressed as a function worker's age (and age squared), with dummy variables capturing gender, marital status, secondary and tertiary level of education, geographical location and industry sub-sector.

Of particular interest to this study is the coefficient for the industry sub-sector. These industry sub-sector wage premiums are expressed as deviations from the employment weighted average wage premium (Krueger \& Summers, 1988). The normalised wage premiums that we obtain can be interpreted as the proportionate difference in wages between employees in a given industrial sub-sector relative to employees with the same observable characteristics across all industrial sectors. The wage premiums we obtained are at the ISIC two-digit manufacturing level to align with the second stage of estimation.

\subsection{Explaining Wage Premiums (second stage)}

This study applies the method designed by Krueger and Summers (1988) and HaiskenDeNew and Schmidt (1997), which calculates the employment-weighted average of wage differentials for all sectors, and the resulting statistics are the proportionate difference in wages between an employee in a given sector and the average employee of all sectors (referred as the normalised wage premiums). In other words, having obtained industry subsector dummies from equation (1), the study attempts to make a linear transformation and normalisation of industry dummies and adjust the standard errors accordingly. The sum of coefficients on the industry dummies weighted by the share of industry employment in the sample is zero. This procedure allows deviations from an overall average rather than from a base category. 
The estimated wage premiums from the first stage estimation are linked with explanatory variables which reflect trade liberalisation and labour characteristics as follows,

$W P_{i t}=\beta_{0}+\beta_{1}\left(L P_{i t}\right)+\beta_{2}\left(S K I L L_{i t}\right)+\beta_{3}\left(\operatorname{TARIFF}_{i t}\right)+\beta_{4}\left(I I M P_{i t}\right)+\beta_{5}(E X P)+\beta_{6}\left(F D I_{i t}\right)+\mu_{i t}(2)$

Where $\boldsymbol{W P}$ = wage premiums of an industrial sub-sector $\boldsymbol{i}$ in year $\boldsymbol{t}(\boldsymbol{t}=1991,1994,1997$, 2000, 2003 and 2007), $\boldsymbol{L P}$ = labour productivity (defined as value-added per worker), SKILL $=$ the share of skilled workers to total workers, TARIFF $=$ industrial tariffs, $\boldsymbol{E X P}=$ export per worker across sub-sectors (exports divided by number of workers), IIMP = intermediate input import per worker (defined as intermediate inputs divided by number of workers), FDI $=$ foreign direct investment per worker and $\boldsymbol{u}=$ error term.

The labour productivity and skill variables are intended to reflect labour characteristics in an industry sub-sector. The variable $\boldsymbol{L P}$ is expected to be positively associated with wage premiums, indicating that higher productivity in an industry sub-sector will be rewarded with higher wages. Similarly, it is also expected that higher skill intensity, SKILL, of a sub-sector is associated with higher wage premiums.

The remainder of explanatory variables are proxies for trade liberalisation. Pavnick et.al. (2004) explain that domestic product tariffs (TARIFF) are positively associated with product price, which in turn are positively associated with wages. Therefore, tariff reduction should lead to a proportional decline in industry wages and make the workers who were previously protected worse off. However, trade openness is also expected to increase the demand for, and productivity of, the abundant unskilled labour and may therefore narrow the wage gap (Avalos and Savvides, 2006).

Jonsson and Subrmanian (2001) and Sjoholm (1997) explain that exporting enables firms to learn new technology, so they tend to produce a higher quality product. In addition, export firms have been found to earn higher price-cost margins than firms that focus only on domestic markets. So, exporting firms can hire workers at higher wage rate, raising the wage premium for workers who work for them. However, in practice any increase in exports per worker $(\boldsymbol{E X P})$ can result in decreased or increased wage premiums depending on the nature of sub-sectors. If the exporting sectors are labour intensive and because of increased 
competition operate with low price-cost margins it is likely that the wage premium will be relatively low.

It is possible for a reduction in input tariffs (IIMP) to have a larger impact on productivity and wages than final output tariffs (Amiti and Cameron, 2012). The resulting increase in intermediate-product imports are expected to have positive effects on industrial wage premiums. Generally, intermediate-product imports would be expected to be cheaper after trade liberalisation and have better quality than those produced by local firms, reducing the unit cost of the final product. As such, it is affordable to hire workers at the higher wage rate. Martin (2009) supports the idea that firm-level imports can be a wage determinant. Firms with high intermediate- product imports tend to increase their salaries for their workers.

Finally, $\boldsymbol{F D I}$ is expected to have a positive influence on the manufacturing wage premiums. This is based on the idea that trade liberalisation will allow a firm to transfer production activities from developed to developing countries. The FDI inflow will make developing countries become relatively more capital-intensive in their industries. As capital is likely to complement skilled workers, the demand for skilled labour will increase, thereby raising wage premium for workers in industries where FDI is prevalent.

\section{RESULTS}

\subsection{Wage Premiums Estimation ( $1^{\text {st }}$ stage $)$}

Table 1 shows the result of equation 1 separately for each sample year (1991, 1994, 1997, 2000, 2003 and 2007). We generally observe robust results and the a priori expected signs for estimated coefficients. Wages increase with age but at a decreasing rate as evidenced by a positive coefficient for age and negative coefficient for age squared. If all other variables are held constant, workers receive their highest wage at the age of 40. Male workers earn more relative to female workers, although this effect appears to have reached a peak and is now diminishing over more recent years. For example, in 1991 male workers earned around 42 per cent higher wages than female workers, increasing to 67 per cent in 1997, then decreasing to 24 per cent by 2007. In addition, married workers receive on average between 5 and 16 per cent more than their single counterparts. 
Table 1: The Results of the Wage Equation: 1991 - 2007

\begin{tabular}{|c|c|c|c|c|c|c|}
\hline Variables & 1991 & 1994 & 1997 & 2000 & 2003 & 2007 \\
\hline Age & $0.0792 * * *$ & $0.0698 * * *$ & $0.1083^{* * *}$ & $0.1333 * * *$ & $0.0693 * * *$ & $0.0649 * * *$ \\
\hline Age squared & $-0.0006^{* * *}$ & $-0.0006 * * *$ & $-0.0010 * * *$ & $-0.0013 * * *$ & $-0.0008 * * *$ & $-0.0008^{* * *}$ \\
\hline Male & $0.4206 * * *$ & $0.6831^{* * *}$ & $0.6768 * * *$ & $0.5659 * * *$ & $0.2258 * * *$ & $0.2428 * * *$ \\
\hline Married & $0.1627^{* * *}$ & $0.05956 * *$ & $0.0710 * *$ & $0.1261^{* * *}$ & $0.0606 * * *$ & $0.0554 * * *$ \\
\hline Secondary & $0.7301^{* * *}$ & $1.0617 * * *$ & $1.0313 * * *$ & $0.9432 * * *$ & $0.2820 * * *$ & $0.2777 * * *$ \\
\hline University & $2.2291^{* * *}$ & $2.6947 * * *$ & $2.6847 * * *$ & $2.6101 * * *$ & $1.0641^{* * *}$ & $1.0919 * * *$ \\
\hline Central & $-0.8278 * * *$ & $-0.6121 * * *$ & $-0.5990 * * *$ & $-0.1587 * * *$ & $-0.2358 * * *$ & $-0.2407 * * *$ \\
\hline North & $0.2054 * *$ & $-0.6815 * * *$ & $-0.8349 * * *$ & $0.5816^{* * *}$ & $-0.5839 * * *$ & $-0.6413^{* * *}$ \\
\hline Northeast & $0.5958 * * *$ & $-0.6437 * * *$ & $-0.4932 * * *$ & -0.0135 & $-0.6244 * * *$ & $-0.5675 * * *$ \\
\hline South & $-0.3014 * * *$ & $-0.6106 * * *$ & $-0.5287^{* * *}$ & $-0.3358 * * *$ & $-0.4328 * * *$ & $-0.4146 * * *$ \\
\hline $\begin{array}{l}\text { Indus. fixed } \\
\text { effect }\end{array}$ & Yes & Yes & Yes & Yes & Yes & Yes \\
\hline Observation & 9,908 & 14,962 & 7,098 & 30,028 & 46,905 & 50,599 \\
\hline R squared & 0.2091 & 0.2835 & 0.3153 & 0.3041 & 0.4374 & 0.50107 \\
\hline
\end{tabular}

Note:

$$
\ln (\text { WAGE })=f(\text { AGE, GENDER, MARITAL STATUS, EDUCATION, LOCATION, }
$$
INDUSTRY SUB SECTORS)

*Significant at $10 \%$, **Significant at 5\%, ***Significant at $1 \%$

Source: authors' calculations

As a worker's level of education increases, likewise their estimated wage increases, consistent with human capital theory. However, because the supply of more educated workers has increased over time with more individuals staying in education longer, the return to additional education has decreased over time. In 1991 workers with secondary school education earned wages around 73 per cent higher than those with only primary school education. However, the return to secondary education decreased to 27 per cent by 2007 . Similarly, university graduates commanded wages around 222 per cent greater than those with only primary school education in 1991, but this also decreased to around 109 per cent by 2007. Finally, compared to the wage rate of workers in Bangkok in 2007, workers in the North of Thailand had relatively lower wage rates, followed by workers in the North East, the 
South, and Central, respectively. The wage differential between workers in Bangkok and the Central area has decreased while the North, Northeast, and South have been relatively stable.

However, of greater importance to this study is the estimation of the two-digit level industry coefficients, representing our wage premiums. Table $2^{6}$ displays the industry wage premiums after controlling for the above characteristics of a worker, which were estimated using a fixed effect model. In 2007, relatively higher wage premiums were observed in coke refined petroleum products and nuclear fuel (ISIC-23), chemicals and chemical products (ISIC-24), publishing, printing and reproduction of recorded media (ISIC- 22) and motor vehicles, trailers and semi-trailers (ISIC-34). In contrast, significantly lower premiums are estimated in food and beverage (ISIC-15), textiles (ISIC-17), dressing of leather (ISIC-19) and wood and products of wood and cork (ISIC-20).

One can hypothetically compare the changes in wages of a worker with identical characteristics moving from one sector to another. For example, in 2007 a worker with the same observable characteristics who switched from ISIC-15 (food and beverages) where the wage discount is -0.1063 to ISIC-23 (coke, refined petroleum products and nuclear fuel) where the wage premium is 1.1126 , would experience a 122 per cent $(1.1126-(-0.1063))$ increase in their monthly wage.

\footnotetext{
${ }^{6}$ ISIC classification: 15; food and beverage, 16: tobacco, 17: textiles, 18: wearing apparel, 19: dressing of leather, 20: wood, 21: paper, 22: publishing, printing and recorded media, 23: petroleum products and nuclear fuel, 24: chemicals, 25: rubber and plastics, 26: other nonmetallic minerals, 27: basic metals, 28: fabricated metal, 29: machinery and equipment, 30: office, computing machinery, 31: electrical machinery, 32: communication equipment, 33: medical, precision and optical instruments, watches and clocks, 34: motor vehicles, trailers and semi-trailers, 35: other transport equipment, 36: furniture.
} 


\section{[Insert Table 2]}

Table 2: Manufacturing Wage Premium between 1991 and 2007

\begin{tabular}{|c|c|c|c|c|c|c|}
\hline Industry & 1991 & 1994 & 1997 & 2000 & 2003 & 2007 \\
\hline 15:food and beverage & $\begin{array}{c}-0.1409 * * * \\
(0.0163)\end{array}$ & $\begin{array}{c}-0.0649 * * * \\
(0.0070)\end{array}$ & $\begin{array}{c}-0.1166^{* * *} \\
(0.0101)\end{array}$ & $\begin{array}{c}-0.0827 * * * \\
(0.0049)\end{array}$ & $\begin{array}{c}-0.1246 * * * \\
(0.0052)\end{array}$ & $\begin{array}{c}-0.1063^{* * *} \\
(0.0052)\end{array}$ \\
\hline 16: tobacco & $\begin{array}{c}0.3519 * * * \\
(0.1072)\end{array}$ & $\begin{array}{c}0.0201 \\
(0.0525)\end{array}$ & $\begin{array}{c}0.3278)^{* * *} \\
(0.0833)\end{array}$ & $\begin{array}{c}-0.1880 * * * \\
(0.0357)\end{array}$ & $\begin{array}{c}-0.1833^{* * *} \\
(0.0374)\end{array}$ & $\begin{array}{c}-0.1148 * * * \\
(0.0408)\end{array}$ \\
\hline 17: textiles & $\begin{array}{c}-0.3402 * * * \\
(0.0470)\end{array}$ & $\begin{array}{c}-0.2334 * * * \\
(0.0261)\end{array}$ & $\begin{array}{l}-0.0282 \\
(0.0331)\end{array}$ & $\begin{array}{c}-0.1943 * * * \\
(0.0155)\end{array}$ & $\begin{array}{c}-0.1792^{* * *} \\
(0.0100)\end{array}$ & $\begin{array}{c}-0.2202^{* * *} \\
(0.0108)\end{array}$ \\
\hline 18: wearing apparel & $\begin{array}{c}-0.3281 * * * \\
(0.0812)\end{array}$ & $\begin{array}{c}-0.1991 * * * \\
(0.0479)\end{array}$ & $\begin{array}{c}-0.1602^{*} \\
(0.0872)\end{array}$ & $\begin{array}{c}-0.1930 * * * \\
(0.0089)\end{array}$ & $\begin{array}{c}-0.1918^{* * *} \\
(0.0085)\end{array}$ & $\begin{array}{c}-0.2315^{* * *} \\
(0.0086)\end{array}$ \\
\hline 19: dressing of leather & $\begin{array}{c}-0.1746 * * * \\
(0.0212)\end{array}$ & $\begin{array}{c}-0.1012 * * * \\
(0.0127)\end{array}$ & $\begin{array}{c}-0.1209 * * * \\
(0.0203)\end{array}$ & $\begin{array}{c}-0.0522^{* * *} \\
(0.0132)\end{array}$ & $\begin{array}{c}-0.0613^{* * *} \\
(0.0152)\end{array}$ & $\begin{array}{c}-0.0815^{* * *} \\
(0.0164)\end{array}$ \\
\hline 20: wood & $\begin{array}{c}-0.4018^{* * *} \\
(0.0397)\end{array}$ & $\begin{array}{c}-0.1207 * * * \\
(0.0203)\end{array}$ & $\begin{array}{c}-0.1493 * * * \\
(0.0319)\end{array}$ & $\begin{array}{c}-0.2415^{* * *} \\
(0.0147)\end{array}$ & $\begin{array}{c}-0.3826 * * * \\
(0.0146)\end{array}$ & $\begin{array}{c}-0.4478 * * * \\
(0.0146)\end{array}$ \\
\hline 21: paper & $\begin{array}{c}0.1017 \\
(0.0688)\end{array}$ & $\begin{array}{c}0.1744 * * * \\
(0.0381)\end{array}$ & $\begin{array}{c}0.1521^{* * *} \\
(0.0445)\end{array}$ & $\begin{array}{c}0.1220 * * * \\
(0.0242)\end{array}$ & $\begin{array}{c}0.1362 * * * \\
(0.0215)\end{array}$ & $\begin{array}{c}0.1396 * * * \\
(0.0209)\end{array}$ \\
\hline 22: publishing and printing & $\begin{array}{c}0.6075^{* * *} * \\
(0.0423)\end{array}$ & $\begin{array}{c}0.1649 * * * \\
(0.0416)\end{array}$ & $\begin{array}{c}0.2697 * * * \\
(0.0451)\end{array}$ & $\begin{array}{c}0.1469 * * * \\
(0.0276)\end{array}$ & $\begin{array}{c}0.4267 * * * \\
(0.0254)\end{array}$ & $\begin{array}{c}0.3973 * * * \\
(0.0239)\end{array}$ \\
\hline 23: petroleum products and nuclear fuel & $\begin{array}{c}0.1261 \\
(0.0836)\end{array}$ & $\begin{array}{c}0.6024 * * * \\
(0.0954)\end{array}$ & $\begin{array}{c}0.2906^{* *} \\
(0.1198)\end{array}$ & $\begin{array}{c}0.8004 * * * \\
(0.0573)\end{array}$ & $\begin{array}{c}1.1867^{* * *} \\
(0.0555)\end{array}$ & $\begin{array}{c}1.1126 * * * \\
(0.0484)\end{array}$ \\
\hline 24: chemicals & $\begin{array}{c}0.0502 \\
(0.0379)\end{array}$ & $\begin{array}{c}0.2923 * * * \\
(0.0231)\end{array}$ & $\begin{array}{c}0.2634 * * * \\
(0.0242)\end{array}$ & $\begin{array}{c}0.2278 * * * \\
(0.0118)\end{array}$ & $\begin{array}{c}0.5254 * * * \\
(0.0153)\end{array}$ & $\begin{array}{c}0.4213^{* * *} \\
(0.0156)\end{array}$ \\
\hline 25: rubber and plastics & $\begin{array}{c}0.0373 \\
(0.0530)\end{array}$ & $\begin{array}{c}0.0888^{* * *} \\
(0.0268)\end{array}$ & $\begin{array}{l}-0.0503 \\
(0.0360)\end{array}$ & $\begin{array}{c}0.0451 * * * \\
(0.0158)\end{array}$ & $\begin{array}{c}0.0759 * * * \\
(0.0112)\end{array}$ & $\begin{array}{c}0.1252^{* * *} \\
(0.0120)\end{array}$ \\
\hline 26: other non-metallic minerals & $\begin{array}{c}-0.1737^{* * *} \\
(0.0328)\end{array}$ & $\begin{array}{c}0.0572 * * * \\
(0.0150)\end{array}$ & $\begin{array}{c}-0.0019 \\
(0.0189)\end{array}$ & $\begin{array}{c}0.0296 * * * \\
(0.0113)\end{array}$ & $\begin{array}{c}0.0140 * * * \\
(0.0109)\end{array}$ & $\begin{array}{c}0.0423^{* * *} \\
(0.0108)\end{array}$ \\
\hline 27: basic metals & $\begin{array}{c}0.0206 \\
(0.0508)\end{array}$ & $\begin{array}{c}0.2038^{* * *} \\
(0.0287)\end{array}$ & $\begin{array}{c}0.1410 * * * \\
(0.0309)\end{array}$ & $\begin{array}{c}0.1602 * * * \\
(0.0178)\end{array}$ & $\begin{array}{c}0.2960 * * * \\
(0.0195)\end{array}$ & $\begin{array}{c}0.3745^{* * *} \\
(0.0191)\end{array}$ \\
\hline 28: fabricated metal & $\begin{array}{c}0.5980 * * * \\
(0.0237)\end{array}$ & $\begin{array}{c}0.1762 * * * \\
(0.0210)\end{array}$ & $\begin{array}{c}0.1048 * * * \\
(0.0224)\end{array}$ & $\begin{array}{c}0.1217 * * * \\
(0.0139)\end{array}$ & $\begin{array}{c}0.0553^{* * *} * \\
(0.0119)\end{array}$ & $\begin{array}{c}0.0498 * * * \\
(0.0122)\end{array}$ \\
\hline 29: machinery and equipment & $\begin{array}{l}0.0884 * \\
(0.0411)\end{array}$ & $\begin{array}{c}0.2378^{* * *} \\
(0.0207)\end{array}$ & $\begin{array}{c}0.1800 * * * \\
(0.0264)\end{array}$ & $\begin{array}{c}0.2003 * * * \\
(0.0116)\end{array}$ & $\begin{array}{c}0.3188^{* * *} \\
(0.0145)\end{array}$ & $\begin{array}{c}0.3022 * * * \\
(0.0148)\end{array}$ \\
\hline 30: office, computing machinery & $\begin{array}{c}0.0715 \\
(0.0942)\end{array}$ & $\begin{array}{c}0.3688 * * * \\
(0.0482)\end{array}$ & $\begin{array}{c}0.1516^{* * *} \\
(0.0282)\end{array}$ & $\begin{array}{c}0.2373 * * * \\
(0.0122)\end{array}$ & $\begin{array}{c}0.1740 * * * \\
(0.0341)\end{array}$ & $\begin{array}{c}0.3109 * * * \\
(0.0371)\end{array}$ \\
\hline 31: electrical machinery & $\begin{array}{c}-0.3074 * * \\
(0.0904)\end{array}$ & $\begin{array}{c}0.0653 \\
(0.0437)\end{array}$ & $\begin{array}{c}-0.0187 * * * \\
(0.0601)\end{array}$ & $\begin{array}{c}0.0797 * * * \\
(0.0234)\end{array}$ & $\begin{array}{c}0.1767^{* * *} \\
(0.0191)\end{array}$ & $\begin{array}{c}0.2148 * * * \\
(0.0192)\end{array}$ \\
\hline 32: communication equipment & $\begin{array}{c}-0.0937 \\
(0.0710)\end{array}$ & $\begin{array}{c}0.1496^{* * *} \\
(0.0400)\end{array}$ & $\begin{array}{c}0.2000 * * * \\
(0.0521)\end{array}$ & $\begin{array}{c}0.1891 * * * \\
(0.0238)\end{array}$ & $\begin{array}{c}0.2289 * * * \\
(0.0104)\end{array}$ & $\begin{array}{c}0.1686^{* * *} \\
(0.0094)\end{array}$ \\
\hline 33: medical and optical instruments & $\begin{array}{c}0.1157 * * * \\
(0.1206)\end{array}$ & $\begin{array}{c}0.2337^{* * *} \\
(0.0641)\end{array}$ & $\begin{array}{c}0.1970 * * * \\
(0.0670)\end{array}$ & $\begin{array}{c}0.2183^{* * *} \\
(0.0341)\end{array}$ & $\begin{array}{c}0.2282 * * * \\
(0.0292)\end{array}$ & $\begin{array}{c}0.1777^{* * *} \\
(0.0294)\end{array}$ \\
\hline 34: motor vehicles and trailers & $\begin{array}{c}0.1842 \\
(0.0613)\end{array}$ & $\begin{array}{c}0.2059 * * * \\
(0.0459)\end{array}$ & $\begin{array}{c}0.2254^{* * *} \\
(0.0398)\end{array}$ & $\begin{array}{c}0.3045^{* * *} \\
(0.0181)\end{array}$ & $\begin{array}{c}0.3754^{* * *} \\
(0.0166)\end{array}$ & $\begin{array}{c}0.3610^{* * *} \\
(0.0137)\end{array}$ \\
\hline 35: other transport equipment, & $\begin{array}{c}-0.2781 * * * \\
(0.0372)\end{array}$ & $\begin{array}{c}-0.0823 * * * \\
(0.0157)\end{array}$ & $\begin{array}{c}-0.1178 * * * \\
(0.0203)\end{array}$ & $\begin{array}{c}-0.0806 * * * \\
(0.0111)\end{array}$ & $\begin{array}{c}0.1257 * * * \\
(0.0232)\end{array}$ & $\begin{array}{c}0.1557^{* * *} \\
(0.0253)\end{array}$ \\
\hline 36: furniture & $\begin{array}{c}-0.0741 \\
(0.0508)\end{array}$ & $\begin{array}{c}-0.0799 * * * \\
(0.0144)\end{array}$ & $\begin{array}{c}-0.0679 * * * \\
(0.0204)\end{array}$ & $\begin{array}{c}-0.0774 * * * \\
(0.0095)\end{array}$ & $\begin{array}{c}-0.1518 * * * \\
(0.0081)\end{array}$ & $\begin{array}{c}-0.1902^{* * *} \\
(0.0088)\end{array}$ \\
\hline 37:recycling & NA & NA & NA & NA & $\begin{array}{c}-0.2861^{* *} \\
(0.1179)\end{array}$ & $\begin{array}{l}-0.1425 \\
(0.1094)\end{array}$ \\
\hline
\end{tabular}

Note: In the parentheses are standard error based on Haisken-Denew and Schmidt's (1997) method. NA $=$ not available.

*Significant at $10 \%, * *$ Significant at $5 \%, * * *$ Significant at $1 \%$

Source: authors' calculations 


\subsection{Analysing Wage Premiums $\left(2^{\text {nd }}\right.$ stage $)$}

The purpose of this section is to evaluate the impact of trade liberalisation on the industry wage premiums, after controlling for relevant labour market characteristics. The estimated wage premiums from section 5.1 have been pooled to form the dependent variable. The Haisken-DeNew and Schmidt (1997) procedure has been adopted by computing the weighted standard deviations of the computed inter-industry wage premiums and an average of the overall variability of industry wage premiums. The Krueger and Summers (1988) approximation overestimates the differential standard errors of the coefficients in the original regression but the Haisken-DeNew and Schmidt (1997) method corrects this by formulating the problem in terms of RLS to estimate the correct standard errors of the renormalised coefficients. $^{7}$

Thai Industrial surveys are not appropriate for forming a panel, and therefore we aggregated the branch panel at a two-digit sub-sector level in order to get a two-digit industry panel comprising 130 observations. We confirmed that there is no significant correlation between the variables used in each and every model presented in Table 3. The estimated variance inflation factor (VIF) coefficients showed there is no multi-collinearity problem. Finally, any potential simultaneity problem between the variables has been addressed by using instrumental variables (Avalos \& Savvides, 2003; Ing, 2009) within a three-stage least squares (3SLS) framework.

The empirical literature shows that wage premiums can be affected by, (a) the number of skilled workers (b) changes in labour productivity, and (c) increased trade openness (Helpman et al., 2012; Ing, 2009; Avalos and Savvides, 2006). Due to the possibility of skilled workers, labour productivity, and tariffs and exports being endogenous, tests for

\footnotetext{
${ }^{7}$ One of the Reviewers commented that standard errors applicable to second stage are likely to be deflated and bootstrapping standard error estimation may be adopted to overcome this problem. However, It is relevant to note a following quote from MacKinnon (2006; S2) "regression models with dependent errors in which bootstrap methods do not always work well”.
} 
exogeneity and validity of the instruments have been carried out. A perfect instrumental variable may not be easy to establish. One option is to use lagged endogenous variables as instruments subject to the equation error or omitted variables, but they are not serially correlated (Angrist and Krueger, 2001). This study uses the lagged values of endogenous variables as instrumental variables as they are predetermined. This means that they are asymptotically uncorrelated with the disturbance. ${ }^{8}$

Based on these results, this study will treat $L P, S K I L L, T A R I F F, E X P, I I M P$ and FDI as endogenous variables in the model, and instruments will be used in the 3SLS estimation. The model IV1 is a basic model explaining the wage premiums. The finding shows that labour productivity $(\boldsymbol{L P})$ is positive and significant in explaining the manufacturing wage premiums at the 10 per cent level. A 1 per cent increase in $\boldsymbol{L P}$ will increase wage premiums by 15.9 per cent.

Trade liberalisation indicator variables are included in models IV2 to IV4 in various combinations. The tariff level exerts a negative influence on wage premiums, indicating that as tariff levels decline in an industry sub-sector, wage premiums rise. This is perhaps contrary to initial expectations that wage premiums would fall as protection declines. However, the estimated coefficients are relatively small in magnitude, and not always significant. In comparison, an increase in intermediate imports which would be expected from reductions in input tariffs exerts a positive influence on wage premiums as predicted. The coefficient attached to exports per worker is negative, demonstrating that export intensive industries competing in global output markets must survive with lower wage premiums. Finally, FDI did not have a significant influence on wage premiums.

\footnotetext{
${ }^{8}$ The results of exogeneity test and the test for validity of instrument variables are obtained using Stata (see Cameron and Trivedi, 2009). The Durbin-Wu-Hausman test shows that the null hypothesis is rejected for the variables, which indicates that the instrumental variables are required. The over-identification test shows that the null cannot be rejected and suggests the instrumental variables are valid since they are uncorrelated with the error terms. The results of the weak-identification test suggest the same (additional information is available from the authors upon request).
} 
Table 3: Explaining Wage Premiums $\left(2^{\text {nd }}\right.$ stage $)$

\begin{tabular}{lrrrr}
\hline Variable & IV1 & IV2 & IV3 & IV4 \\
\hline LP & $0.1593^{*}$ & $0.2527^{* *}$ & $0.1904^{* * *}$ & $0.0713^{*}$ \\
SKI LL & 0.1565 & 0.3053 & $0.2710^{*}$ & 0.1203 \\
TARIFF & & -0.0067 & $-0.0068^{* *}$ & $-0.0119^{* * *}$ \\
EXP & & $-0.1487^{* *}$ & & $-0.1983^{* *}$ \\
IIMP & & & -0.0218 & $0.1615^{* * *}$ \\
FDI & & & & -0.0444 \\
CONSTANT & -1.8911 & -0.8301 & $-1.7122^{*}$ & 0.5273 \\
\hline N & 105 & 48 & 63 & 19 \\
$r^{2}$ & 0.21 & 0.03 & 0.25 & 0.74 \\
aic & 496 & 628 & 906 & 291 \\
\hline
\end{tabular}

Note:

$W P_{i t}=\beta_{0}+\beta_{1}\left(L P_{i t}\right)+\beta_{2}\left(S K I L L_{i t}\right)+\beta_{3}\left(\operatorname{TARIFF}_{i t}\right)+\beta_{4}\left(I I M P_{i t}\right)+\beta_{5}(E X P)+\beta_{6}\left(F D I_{i t}\right)+\mu_{i t}$

The number of observation varies as variables which are available from the industrial survey are not consistent with labour surveys.

*Significant at $10 \%, * *$ Significant at $5 \%, * * *$ Significant at $1 \%$

Source: authors’ calculations

\section{CONCLUSIONS}

This study analyses the potential effect of trade liberalisation on industry sub-sector wage premiums. We documented the substantial trade liberalisation initiatives applied to the Thai manufacturing sector since the early 1990s. This period of trade liberalisation was shown to coincide with substantial growth in both education levels and productivity of Thai workers. Estimation results showed that in addition to workers' characteristics, industry characteristics 
where workers are employed, are important in determining the wages for workers. After controlling for observable worker characteristics, wage premiums were found to be high in industries identified as capital and technology intensive such as petroleum and chemical products, presumably requiring more skilled workers. As expected then, lower wage premiums were recorded industries predominantly requiring unskilled workers such as food and textile manufacturing.

We then analysed these industry wage premiums with explanatory variables reflecting other labour market characteristics as well as trade liberalisation using two-digit industry panel data. Contrary to expectations, falling output tariffs were (weakly) associated with increased wage premiums. However, export intensive sub-sectors were associated with lower wage premiums, presumable because they are facing a high level of price competition on global output markets where organisations must operate with low price-cost margins. However, the strongest finding was that from our final model which included intermediate imports. An increase in these intermediate imports, which would result from declining input tariffs, exerted a very strong positive influence on wage premiums. However, there were a number of limitations to using ISIC two-digit industry sub-sector level analysis. Thai survey data cannot be matched to explore employer and employees over time. Future research utilising linked employer and employee micro data is likely to provide fruitful further insights. 


\section{REFERENCE}

Angrist, J. D. and Krueger, A. B. (2001), 'Instrumental Variables and the Search for Identification: From Supply and Demand to Natural Experiments', Journal of Economic Perspectives, 15 (4), 69 - 85.

Amiti, M. and Cameron, L. (2012), 'Trade Liberalisation and the Wage Skill Premium: Evidence from Indonesia', Journal of International Economics, 87 (1), 277 - 287.

Avalos, A. and Savvides, A. (2006), 'The Manufacturing Wage Inequality in Latin America and East Asia: Openness, Technology Transfer, and Labour Supply', Review of Development Economics, 10 (4), 553 - 576.

Bank of Thailand (2010a), 'Employment in Thailand', http://www.bot.or.th/Thai/Statistics/EconomicAndFinancial/RealSector/Pages/Index.a spx\# accessed September 7, 2012.

Bank of Thailand (2010b), Growth Rate of Domestic Production in Major Sector, www.bot.or.th, accessed February 1, 2012.

Bank of Thailand (2012a), 'Macro Economic Indicators', Bank of Thailand, Bangkok.

Bank of Thailand (2012b), 'Employment in Thailand', http://www.bot.or.th/Thai/Statistics/EconomicAndFinancial/RealSector/Pages/Index.as px\#, accessed September 7, 2012.

Bhula-or, R. and Kripornsak, P. (2008), 'Trends of Labour Demand for High-Skilled Workers and Their Wages in Thailand', Journal of International Business Research, 7 (1). The Dreamcatchers Group, LLC. ISSN 1544 - 0222.

Booncharoen, S. (2001), 'Industrial Protection in Thailand: Executive Summary and Tables ', Office of Industrial Economics, Thailand Institute of Scientific and Technological Research Bangkok.

Bryant, J. and Rukumnuaykit, P. (2007), 'Labor Migration in the Greater Mekong SubRegion : Does Immigration to Thailand Reduce Wages of Thai Workers? ', Mahidol University Institute for Population and Social Research, Thailand., Mahidol University, Bangkok, 1 - 24. 
Cameron, A. C. and Trivedi, P. K. (2009), 'Microeconometrics Using Stata', A Stata Press Publication, Texas.

Davis, D. R. and Harrigan, J. (2011), ‘Good Jobs, Bad Jobs, and Trade Liberalisation’, Journal of International Economics, 84, 26 - 36.

Earle, D. (2010), 'Skills, Qualifications, Experience and the Distribution of Wages', Tertiary Sector Performance Analysis and Reporting, the Ministry of Education, Wellington.

Feenstra, R. C. and Hanson, G. H. (1996), 'Globalization, Outsourcing, and Wage Inequality', The American Economic Review, 86 (2), 240 - 245.

Ferreira, F. H. G., Leite, P. G. and Wai-Poi, M. (2007), 'The Trade Liberalisation, Employment Flow and Wage Inequality in Brzail', World Institute for Development Economics Research, 2007/58.

Goldberg, P. K. and Pavcnik, N. (2007), 'Distributional Effects of Trade Liberalisation in Developing Countries, Journal of Economic Literature, 45 (1), 39 - 82.

Haisken-Denew, J. P. and Schmidt, C. M. (1997), 'Interindustry and Interregion Differentials: Mechanics and Interpretation', The Review of Economics and Statistics, 79 (3), 516 521.

Helpman, E., Itskhoki, O., Muendler, M-A. and Redding, S. J. (2012), 'Trade and Inequality: from Theory of Estimation, National Bureau of Economic Research, WP 17991.

Hunt, J. (2002), 'The Transition in East Germany: When Is a Ten-Point Fall in the Gender Wage Gap Bad News?', Journal of Labor Economics, 20 (1), 148 - 169.

Ing, L.Y. (2009), 'Lower Tariff, Rising Skill Premium in Developing Countries: Is It a Coincidence?', The World Economy, 32 (7), 1115 - 1133.

Jongwanich, J. and Kohpaiboon, A. (2007), 'Determinants of Protection in Thai Manufacturing', Economic Papers: A journal of applied economics and policy, 26 (3), $276-294$.

Jonsson, G. and Subramanian, A. (2001), 'Dynamic Gains from Trade:Evidence from South Africa', International Monetary Fund Staff Papers 48, 197 - 224. 
Katz, L. F. and Murphy, K. M. (1992), 'Changes in Relative Wages, 1963 - 1987: Supply and Demand Factors', Quarterly Journal of Economics, 107 (1), 35 - 78.

Krueger, A. B. and Summers, L. H. (1988), 'Efficiency Wage and the Inter-Industry Wage Structure', Econometrica (1986-1998), 56 (2), 259 - 293.

Krugman, P. R. (1981), 'Intra-industry Specialization and the Gains from Trade’, Journal of Political Economy, 89 (5), 959 - 973.

Kumar, U. and Mishra, P. (2008), 'Trade Liberalization and Wage Inequality: Evidence from India', Review of Development Economics, 12 (2), 291 - 311.

MacKinnon, J. G. (2006), 'Bootstrap Methods in Econometrics', The Economic Record, 82 (S1), S2 - S18.

Martins, P. 2009, 'Exports, Imports and Wages: Evidence from Matched Firm-WorkerProduct Panels', The Institute for the Study of Labor, University of London, London.

Melitz, M. J. (2003), 'The Impact of Trade on Intra-industry Reallocations and Aggregate Industry Productivity’, Econometrica, 71 (6), 1695 - 1725.

Mishra, P. and Kumar, U. (2005), 'Trade Liberalization and Wage Inequality: Evidence from India', IMF Working Paper, WP/05/20.

National Economic and Social Development Board (2009), 'Macro Economic Indicators', http://www.nesdb.go.th/, accessed September 7, 2012.

National Economic and Social Development Board (2012a), 'Macro Economic Indicators', http://www.nesdb.go.th/ , accessed September 7, 2012

National Economic and Social Development Board (2012b), 'National Income of Thailand ', Bangkok.

National Statistical Office (various issues), 'Labour Force Survey', Bangkok.

National Statistical Office (various issues), 'Industrial Survey', Bangkok.

Pavcnik, N., Blom, A., Goldberg, P. and Schady, N. (2004), 'Trade Liberalization and Industry Wage Structure: Evidence from Brazil', The World Bank Economic Review, 18 (3), $319-344$. 
Phan, P. 2004, 'Trade Liberalization and Manufacturing Performance in Thailand 1990-2000', School of Economics, The University of Wollongong, Wolllongong.

Sangkaew, P. 2013, 'Trade Liberalization, Labour Productivity and Wage Inequality: The Case of the Thai Manufacturing Sector', Unpublished Ph.D. thesis, School of Economics, University of Wollongong, Wollongong.

Sjöholm, F. (1997), 'Exports, Imports and Productivity: Results from Indonesian Establishment Data', Working Paper No. 33, August 1997, Stockholm School of Economics, Stockholm, 1 - 33.

Velde, D. T. and Morrissey, O. (2004), 'Foreign Direct Investment, Skills and Wage Inequality in East Asia', Journal of the Asia Pacific Economy, 9 (3), 348 - 369.

Seguino, S. (2000), 'The Effects of Structural Change and Economic Liberalisation on Gender Wage Differentials in South Korea and Taiwan', Cambridge Journal of Economics, 24 (4), 437 - 459. 